\title{
Psychosocial stress and minor psychiatric disorders among Agentes Socioeducadores ${ }^{1}$
}

\author{
Patrícia Bitencourt Toscani Greco² \\ Tânia Solange Bosi de Souza Magnago ${ }^{3}$ \\ Luis Felipe Dias Lopes ${ }^{4}$ \\ Andrea Prochnow ${ }^{5}$ \\ Juliana Petri Tavares ${ }^{6}$ \\ Natieli Cavalheiro Viero ${ }^{7}$
}

Objective: to ascertain the association between psychosocial stress and the occurrence of Minor Psychiatric Disorders in agentes socioeducadores. Method: a cross-sectional study with 381 agentes socioeducadores from the Centros de Atendimento Socioeducativo in the Brazilian state of Rio Grande do Sul, in 2011. Brazilian versions of the social demand-control-support at work scale were used, and of the Self Reporting Questionnaire-20. Results: the prevalence of minor psychiatric disorders was 50.1\%. The chances of being classified with such a disorder were higher in the high strain work quadrant (OR=2.05; CI95\%=1.03-4.09) and active work quadrant $(\mathrm{OR}=1.99 ; \mathrm{CI} 95 \%=1.09-3.63)$ when compared to that of low strain, after adjustment for potentially confusing factors. Conclusion: there is a positive association between psychosocial stress (high strain and active work) and minor psychiatric disorders among agentes socioeducadores. In order to prevent mental illness among these workers, the planning of health promotion actions is necessary.

Descriptors: Work; Occupational Health; Working Conditions; Mental Disorders; Stress, Psychological.

\footnotetext{
1 'Agentes socioeducadores' are workers in closed or semi-open centers which attend adolescent offenders who are serving sentences or measures established by the judiciary. Translator's note. Paper extracted from Master's Dissertation "Distúrbios Psíquicos Menores em agentes socioeducadores do Rio Grande do Sul", presented to Universidade Federal de Santa Maria, Brazil. Supported by CNPq, process \# 479042/2010-1.

2 MSc, RN, Prefeitura Municipal de Santiago, Brazil. Professor, nursing undergraduate course, Universidade Regional Integrada do Alto Uruguai e das Missões, Campus Santiago, Brazil.

${ }^{3} \mathrm{PhD}$, Adjunct Professor, Departamento de Enfermagem, Universidade Federal de Santa Maria, Brazil.

${ }^{4} \mathrm{PhD}$, Associate Professor, Departamento de Administração, Universidade Federal de Santa Maria, Brazil.

${ }^{5}$ Master's student, Universidade Federal de Santa Maria, Brazil.

${ }^{6}$ Doctoral Student, Universidade Federal de Santa Maria, Brasil. Scholarship holder from CAPES.

7 RN, Pronto Atendimento Municipal, Prefeitura Municipal de Cachoeira do Sul, Brazil.
}

Corresponding Author:

Tânia Solange Bosi de Souza Magnago

Universidade Federal de Santa Maria

Rua José Manhago, 123

Bairro: Camobi

CEP: 97105-430, Santa Maria, RS, Brasil

E-mail: tmagnago@terra.com.br 


\section{Estresse psicossocial e distúrbios psíquicos menores em agentes socioeducadores}

Objetivo: verificar a associação entre estresse psicossocial e a ocorrência de Distúrbios Psíquicos Menores em agentes socioeducadores. Método: estudo transversal com 381 agentes socioeducadores dos Centros de Atendimento Socioeducativo do Rio Grande do Sul, em 2011. Utilizaram-se as versões brasileiras da escala de demanda-controleapoio social no trabalho e do Self-Reporting Questionnaire 20 (SRQ-20). Resultados: a prevalência de distúrbio psíquico menor foi de $50,1 \%$. As chances de ser classificado com tal distúrbio foram maiores no quadrante trabalho em alta exigência $(O R=2,05$; IC95\%=1,03-4,09) e trabalho ativo (OR=1,99; IC95\%=1,09-3,63), quando comparados ao de baixa exigência, após ajuste por potenciais fatores de confusão. Conclusão: há associação positiva entre estresse psicossocial (alta exigência e trabalho ativo) e distúrbios psíquicos menores em agentes socioeducadores. Faz-se necessário o planejamento de ações de promoção à saúde, a fim de prevenir o adoecimento mental desses trabalhadores.

Descritores: Trabalho; Saúde do Trabalhador; Condições de Trabalho; Transtornos Mentais; Estresse Psicológico.

\section{Estrés psicosocial y disturbios psíquicos menores en agentes socio- educadores}

Objetivo: verificar la asociación entre estrés psicosocial y la ocurrencia de Disturbios Psíquicos Menores en agente socio-educadores. Método: Estudio transversal con 381 agentes socio-educadores de los Centros de Servicio Socio-educativo de Rio Grande do Sul, en 2011. Se utilizaron las versiones brasileñas de la escala de Demanda-control-apoyo social en el trabajo y del Self Reporting Questionnaire-20. Resultados: la superioridad de disturbio psíquico menor fue del 50,1\%. Las chances de ser clasificado con tal disturbio fueron mayores en el cuadrante de trabajo en alta exigencia $(\mathrm{OR}=2,05$; IC95\%=1,03$4,09)$ y trabajo activo $(O R=1,99 ; \mathrm{IC} 95 \%=1,09-3,63)$ cuando se comparó a lo de baja exigencia, después del ajuste por potenciales factores de confusión. Conclusión: hay asociación positiva entre estrés psicosocial (alta exigencia y trabajo activo) y disturbios psíquicos menores en agentes socio-educadores. Se hace necesaria la planificación de acciones de promoción a la salud, a fin de precaver la enfermedad mental de eses trabajadores.

Descriptores: Trabajo; Salud Laboral; Condiciones de Trabajo; Trastornos Mentales; Estrés Psicológico.

\section{Introduction}

The agentes socioeducadores work for the Fundação de Atendimento Socioeducativo* of Rio Grande do Sul (FASE/RS) and work in the Centros de Atendimento Socioeducativo** (CASEs). Their work activities are connected with adolescents who are under correctional education, accompanying them on visits, court hearings, and health consultations; the planning and monitoring of workshops, leisure activities and sports.

The agentes socioeducadores are responsible for implementing the actions programmed in the Individual Plan for the Adolescent(1); they are exposed to a work environment which can brings risks to their physical,

* Foundation for Socio-Educational Assistance, the organization providing said support. Translator's note.

** The centers where the adolescent offenders are serving their sentences. Translator's note. 
moral and psychiatric integrity. The activities undertaken are defined by high concentration, accelerated rhythm, unpredictability, tension and a constant state of alert, which constitute potentially stressing work conditions.

The workplace stress may derive from the imbalance between the demands of professional practice and the worker's coping ability. It may also result from the interaction between high psychological demands, low control over the work process and low social support at work $^{(2)}$. Among the models which investigate psychosocial stress, Karasek's proposal from the nineteen-seventies stands out. It is a bi-dimensional Demand-Control Model (DCM) which relates two psychosocial aspects in the work environment - psychological demands and control over the work - to the risk of illness ${ }^{(2-3)}$.

The control over the work is related to the use of skills for carrying out tasks (learning, repetitivity, creativity) and the decision-making authority (skill for taking decisions about the work itself, influence in the work group, and influence on managerial policy). The psychological demands are related to the psychological demands faced by the worker in carrying out his or her tasks (time pressures and level of concentration demanded by the work) ${ }^{(2-4)}$.

Four types of experiences in the work psychosocial environment are established in the DCM, starting from the combination of high and low levels of psychological demands and demands for control: high strain (high demand and low control), active work (high demand and high control), passive work (low demand and low control) and low strain (low demand and high control). Considering these four situations, the high strain presents the most adverse reactions of psychological strain, which may be evidenced through fatigue, anxiety, depression, and physical infirmity(2).

Minor Psychiatric Disorders (MPDs) stand out among the repercussions of psychosocial stress. They present a scenario with symptoms of anxiety or depression or psychosomatic symptoms, which do not meet all the diagnostic criteria for mental disorders (with anxious, depressive or psychosomatic symptoms)(5). Sadness, anxiety, fatigue, reduction in concentration, irritability and insomnia are common symptoms in individuals with MPDs, and can lead to functional incapacity(6).

The relationship between psychosocial aspects of work and MPD has been evaluated in lecturers at federal universities ${ }^{(7)}$, nursing staff $^{(8)}$, doctors $^{(9)}$ and truck drivers ${ }^{(10)}$. The prevalence of MPD in these studies varied between $6.1 \%$ and $33.3 \%$. The high strain was associated with MPDs, as were certain significant sociodemographic variables (being female, a young adult, having little education, and being overloaded with tasks at home) and labor-related (low social support, being undervalued professionally, doing shift work and working long hours). Such observations denote the MPDs as an important public health problem to be investigated. A gap was found in Brazilian knowledge production referring to this issue and to the population which the present study focused on.

In the state of Rio Grande do Sul, according to data from the Center for Epidemiological Surveillance ${ }^{(11)}$, mental disorders are the second largest cause of staff taking leave from work. From this perspective, this study is justified, as situations which may affect workers' mental health are common in the context of the work done by agentes socioeducadores: living with the risk of violence (physical and psychological), a constant state of alert, rigidly following prescribed steps, a need for rapid decision-making and responsibility for keeping the environment calm and functioning well.

These are situations which make a population vulnerable to work-related psychological illness. This shows the importance of identifying work situations which can affect agentes socioeducadores psychologically, with the aim of reducing or eliminating such situations so as to promote these workers' health.

It was in this context, then, that the present work aimed to evaluate the association between psychosocial stress and the occurrence of Minor Psychiatric Disorders among agentes working in the CASE/RS. It is intended to contribute to nursing, and to workers' health in general, as it presents a panorama of the agentes socioeducadores' mental health; thus it makes it possible to plan and implement health promotion actions for all workers involved in attending this client group.

\section{Method}

This epidemiological cross-sectional study was undertaken in the CASEs/RS. These are located in the capital, Porto Alegre, where there are six units located in a FASE complex, and elsewhere in the state, in seven units spread across seven different municipalities.

The study population was comprised of 819 agentes socioeducadores from the CASE/RS: 486 agentes socioeducadores in Porto Alegre and 333 elsewhere in the state of Rio Grande do Sul. The sample itself was made up of 381 agentes socioeducadores, considering a sampling error of $3.68 \%$, a proportion estimated at $50 \%$ and a significance level of $5 \%$. The selection of the sample was random by CASE. 
Agentes socioeducadores of both sexes were included in the study, located in the CASEs/RS. In the case of those returning from holidays or any other form of leave, inclusion was implemented only after 30 days of being back at work (a collection criteria of the SRQ20 research instrument). Agentes socioeducadores who were on leave due to health reasons, suspension or any other form of removal from work were excluded from the study. Recruitment was carried out individually in the workplace, based on provision of information about the research's objectives, purpose, risks and benefits. After assent and signing of the Terms of Free and Informed Consent, they received the research questionnaire for filling out.

Data collection was carried out in March - August of 2011, by certified research assistants. The instruments used were: a self-applied questionnaire, with questions related to the subject's sociodemographic profile (age, sex, level of schooling, race, marital status), work profile (length of service as an agente socioeducador, shift worked, undertaking of capacity-building, weekly hours, satisfaction with workplace, and need for leave from work); the summarized version of the Job Content Questionnaire, the Job Stress Scale(3) and the SelfReporting Questionnaire 20 (SRQ-20), validated for Brazil(12) for investigating MPD. Questions were included referring to health habits and conditions (use of tobacco, use of alcohol (CAGE)(13), the carrying out of regular physical activity, time for leisure, use of medication and need for medical or psychological consultations).

The exposure to psychosocial dimensions 'psychological demands' and 'control over work' (independent variable) was evaluated through the Job Stress Scale (JSS) (3), also termed the Swedish DemandControl-Social Support Scale (DCS). This version contains 17 questions, of which five evaluate demand, six control and six social support.

In order to dichotomize the demand and control variables, the average was used as a cut-off point. Based on these two dichotomized dimensions of 'high' and 'low', four categories were constituted: low strain (high control and low demand - reference category), active work (high control and high demand), passive work (low control and low demand) and high strain (low control and high demand - category of highest exposure) (2). Social support was dichotomized, according to the average scores, into high and low social support.
The Minor Psychiatric Disorders (dependent variable) were evaluated according to the scores obtained in the Self-Reporting Questionnaire 20 (SRQ20) validated for Brazil in the nineteen-eighties(12). The cut-off point used for suspicion of MPD among both men and women was seven or more positive responses ${ }^{(14)}$.

The program Epi-info $\AA$, version 6.4 , was used for the insertion of the data, with data typed twice independently. After checking for errors and inconsistencies, data analysis was undertaken with

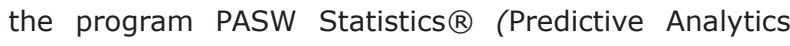
Software, from SPSS Inc., Chicago - USA) 18.0 for Windows.

The JSS and SRQ-20's internal consistencies were measured by Cronbach's Alpha Coefficient. Pearson's Chi-squared test and Fisher's Exact test were used to ascertain whether the associations found presented statistical significance $(p<0.05)$. The multivariate analysis was calculated using binary logistic regression. The low strain quadrant was considered as the reference category. For selection of the possible confounding variables associated as much with exposure as with outcome, a level of significance of $25 \%(p \leq 0.25)$ was established, using the chi-square. In the bi-variate analyses, the following variables appeared as potentially confounding factors: suspicion for alcoholism (according to the CAGE questionnaire), leisure time, satisfaction at work, work schedule, work shift, physical activity, leave from work and being under psychological treatment. Logistic regression models were run with all these variables. The variables were withdrawn from the models as the $p$ value went over $25 \%$. The HosmerLemeshow Test was used to ascertain the regression models' suitability. In this test, the values varied from zero $(0)$ to one (1); the closer the value was to one, the better the model is ${ }^{(15)}$.

The research was authorized by FASE/RS and the Federal University of Santa Maria's Research Ethics Committee, under Protocol no 23081. 019161/2010-08, and Certificate of Presentation for Ethical Appreciation (CAAE): 0333.0.243.000-10, on 14 ${ }^{\text {th }}$ December 2010. The research is in accordance with Resolution 196/96 of the Brazilian National Health Council*.

\section{Results}

The agentes socioeducadores in Rio Grande do Sul, in terms of their principal sociodemographic

\footnotetext{
* Resolution 196/96 establishes guidelines and regulatory norms for research involving human beings. Translator's note.
} 
characteristics, are predominantly female (55.8\%), between 27 and 44 years of age (51.9\%) (average = 44.4 years of age; SD=8.17), Caucasian $(75 \%)$, have a degree or post-graduate qualification (54.3\%), are married or with a partner $(64.4 \%)$ and have one to two children (62.4\%).

Regarding health and habits, a higher percentage of the agentes had never smoked (58.2\%) and did not show any signs of alcoholism (89.3\%); slept between five and eight hours per day (89.8\%); did not carry out regular physical activity $(67.2 \%)$, and stated that they sometimes had time for leisure (50.3\%). Regarding use of medication, $62.8 \%$ referred to making use of some or other type of medication, of whom $92 \%$ stated that the use was on medical advice. The main medications mentioned were: anti-hypertensives, anti-depressives, anxiolytics, Thyroxine T4 and analgesics. Questioned about the need for medical or psychiatric treatment over the previous year, $79.6 \%$ and $35.5 \%$, respectively, answered in the positive.

Regarding work profile, $70.1 \%$ had worked as agentes for up to ten years, and $53.7 \%$ had worked on the same shift for up to eight years. The percentage of the agentes in the two shifts was similar. Of the total of the agentes, $67.5 \%$ worked up to 40 hours per week and $9.2 \%$ held a second job. Among the latter, $71.4 \%$ stated that the other job had a work load of up to 20 hours, and $53.4 \%$ had worked in the other job for at least six years. The majority (55\%) affirmed that they had not received training or capacity-building; that there were not enough agentes at work (80.3\%) and that they were not satisfied with their workplace (52.3\%). Regarding health-problem related leave from work, $36.1 \%$ had needed up to nine days and $16.6 \%$ from 10 to 24 days.

The general internal consistency of the JSS scale was 0.62 (psychological demands $a=0.74$ and control $a=0.55$ ). In terms of the quadrants, $30.2 \%$ of the agentes socioeducadores were classified in the low strain quadrant, $29.7 \%$ in Active work, $21 \%$ in Passive work and $19.2 \%$ in work in high strain.

A higher percentage of the agentes socioeducadores who needed psychological counseling and those who did not have time for leisure were classified in the active work and high strain quadrants $(p<0.0001)$. Among those workers who worked on the day shift, or who were not satisfied with their workplace, or who needed from 25 to 99 days of leave from work, higher percentages were found in the active work quadrant $(p<0.05)$. Among those with up to six years' service in the other job, the highest percentage was in the passive work quadrant $(p=0.001)$. Among those who worked the night shift, those who claimed that there were enough workers at work and those who stated that they were satisfied with their workplace were found most frequently in the low strain quadrant $(p<0.0001)$, while among those with 10 to 24 days of leave from work, there was a greater frequency for the high strain quadrant $(p=0.047)$. The remaining socio-demographic variables did not present statistically significant associations between the groups ( $p>0.05$ ) when considering the DCM quadrants.

The global prevalence for suspicion of MPD in agentes socioeducadores was $50.1 \%$. The Cronbach Alpha coefficient of the SRQ-20 was 0.86. Higher frequencies of suspicion of MPD were identified among female agentes, aged up to 44 years old, with undergraduate or post-graduate degrees, who had never smoked, who displayed signs of alcoholism, who did not take physical exercise, who did not have time for leisure, who were on medications and who needed medical or psychological treatment $(p<0.05)$. This was also the case for agentes who had been in the institution or role for less time, who had a second job, who considered the work force to be insufficient in numbers, who were not satisfied with their workplace, or who referred to having capacity-building sometimes $(p<0.05)$. Regarding the other variables linked to work, there were no significant differences between the groups evaluated and suspicion of MPD ( $p>0.05)$.

Table 1 - Prevalence of Minor Psychiatric Disorders (MPD), prevalence ratios (PR) and their respective confidence intervals, according to the levels of the work's psychological demands, control over the work, and social support. Rio Grande do Sul, Brazil, 2011

\begin{tabular}{|c|c|c|c|c|c|}
\hline Dimensions - Demand-Control Model & $\mathrm{n}$ & $\%$ & PR & $\mathrm{Cl}$ & $p$ \\
\hline \multicolumn{6}{|l|}{ Psychological demands } \\
\hline Low $^{*}$ & 78 & 40.0 & - & - & \\
\hline High & 113 & 60.8 & 1.52 & $1.23-1.87$ & $<0.0001$ \\
\hline \multicolumn{6}{|l|}{ Control over the work } \\
\hline Low & 87 & 56.9 & 1.25 & $1.02-1.52$ & 0.031 \\
\hline High* $^{*}$ & 104 & 45.6 & - & - & \\
\hline
\end{tabular}


Table 1 - (continuation)

\begin{tabular}{lccccc}
\hline Dimensions - Demand-Control Model & $\mathbf{n}$ & $\%$ & PR & Cl & p \\
\hline Social support & & & & & $<0.0001$ \\
Low support & 116 & 63.4 & 1.67 & $1.36-2.06$ & - \\
High support & 75 & 37.9 & - & - & \\
\hline
\end{tabular}

* reference category

PR: Prevalence ratio; CI: Confidence interval.

In Table 1, among the agentes socioeducadores classified as having high demand, low control and low social support, higher and more significant prevalencies of MPD were found - of $52 \%, 25 \%$ and $67 \%$, respectively.

Table 2 - Unadjusted and adjusted associations between the quadrants of the Demand-Control Model (DCM) and Minor Psychiatric Disorders (MPD). Rio Grande do Sul, Brazil, 2011

\begin{tabular}{|c|c|c|c|c|c|}
\hline \multirow[b]{2}{*}{ Demand-Control Model } & \multicolumn{4}{|c|}{ MPD } & \multirow{2}{*}{$\begin{array}{c}\text { Hosmer and } \\
\text { Lemeshow Test }\end{array}$} \\
\hline & L-S & $\begin{array}{c}\text { PW } \\
\text { OR (CI95\%) }\end{array}$ & $\begin{array}{c}\text { AW } \\
\text { OR (CI95\%) }\end{array}$ & $\begin{array}{c}\text { H-S } \\
\text { OR (CI95\%) }\end{array}$ & \\
\hline Unadjusted Association* & 1.00 & $1.85(1.03-3.32)$ & $2.63(1.54-4.51)$ & $3.74(2.01-6.94)$ & 1.00 \\
\hline Model $1^{\dagger}$ & 1.00 & $1.66(0.81-3.41)$ & $1.53(0.77-3.03)$ & $1.92(0.81-4.15)$ & 0.192 \\
\hline Model $2^{\ddagger}$ & 1.00 & $1.73(0.90-3.32)$ & 1.99(1.09-3.63) & $2.05(1.03-4.09)$ & 0.769 \\
\hline Model $3^{\S}$ & 1.00 & $1.87(1.01-3.48)$ & $2.47(1.39-4.39)$ & $2.90(1.49-5.63)$ & 0.610 \\
\hline
\end{tabular}

L-S: low strain (reference category) PW: Passive work AW: Active work H-S: high strain OR: Odds ratio; CI: Confidence Interval.

* Demand-control groups;

+ Demand-control groups + CAGE + leisure time + satisfaction with work + Insufficient workforce + work shift + physical activity + leave from work;

₹ Demand-control groups + leisure time + satisfaction with work + physical activity;

$\S$ Demand-control groups + psychological counseling.

The unadjusted logistic regression analysis demonstrated that, compared to those in the low strain group $(p<0.0001)$, the agentes socioeducadores classified in the other three quadrants of the DCM showed from 1.85 to 3.74 times more likelihood of developing MPD. According to the Hosmer and Lemeshow Test, Model 2 best explains the association. This being so, even after adjusting for the potential confounding variables (leisure time, satisfaction with work, physical activity) the chances of the agentes socioeducadores being classified with MPD remain in the high strain ( $\mathrm{OR}=2.05 ; \mathrm{CI} 95 \%=1.03-4.09)$ and active work $(\mathrm{OR}=1.99 ; \mathrm{CI} 95 \%=1.09-3.63)$ groups (Table 2$)$.

\section{Discussion}

On evaluating the percentage of MPD among agentes socioeducadores according to the DCM quadrants, it was observed that the prevalence of MPD was highest in the quadrant with the greatest exposure (high strain), followed by the active work and passive work quadrants. The principal prediction established in the DCM is that the majority of adverse reactions to psychological demands (fatigue, anxiety, physical illnesses) occur when the work's demands are high and the control over the work is low (high strain)(2). This prediction was confirmed in this study, evidencing the positive association between work in high strain and MPD.
The agentes socioeducadores who were exposed simultaneously to high psychological demands and low control at work (work in high strain) presented twice the probability of occurrence of MPD of those who were not exposed (low strain). Other studies have found an association between workers in high strain and higher probabilities of being suspected of having MPD, even after adjustments for the potential confounding variables $^{(4,7-9,16)}$.

However, agentes classified in the active work quadrant also presented almost twice the probability $(\mathrm{OR}=1.99 ; \mathrm{CI} 95 \%=1.09-3.63)$ of suspicion of MPD, when compared to the agentes allocated in the low strain quadrant. Equally, studies have indicated active work as the quadrant associated with suspicion of $M_{P D}(4,7-8)$. The fact that a higher percentage of these workers are exposed to situations of high psychological demands may be seen as worrying, considering that these predispose workers to illness and are described in some studies as the variable in this model which is identified most closely with the occurrence of $\operatorname{MPD}^{(8-9,17)}$.

In this study, as in others ${ }^{(8-9,17)}$, high control at work seems not to have minimized the negative effects of the work's high psychological demands on the workers' mental health. An important aspect pointed out in one study ${ }^{(4)}$ related to strain in high control situations is that the high levels of control at work entail the growth of 
responsibilities resulting from the increase in autonomy, which in its turn can provoke greater tension, negatively interfering in the workers' health.

In this aspect - regarding the work of the agentes socioeducadores - these responsibilities resulting from the high control may be a reflection of the worker's duties themselves. That is, most of the time, the adolescents are under the responsibility of the agentes, and maintaining order in the CASEs, so as to avoid the different situations of violence that can occur, depends on the decisions taken by the agentes on such occasions. There is a need for further studies to understand this relationship.

The prevalencies of $52 \%$ higher levels of MPD among the agentes classified as high psychological demands, and of $25 \%$ higher levels among those with low control, converge on the assertion that the agentes socioeducadores' working conditions in the CASE/RS impose harmful strain, with consequences for these workers' psychiatric health.

In this research, the majority of the agentes socioeducadores were classified in the group with low social support (63.4\%). It was ascertained that $70 \%$ of the agentes classified in the high strain quadrant and with low social support were suspected of having MPD. Another important observation of this study, however, was that $56.5 \%$ of the agentes classified in high strain, despite mentioning high social support, were also suspected of MPD. The association between low social support and MPD has been reported in other

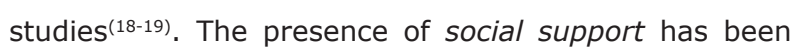
associated with better health levels, as high levels of support act as a protective factor against the risks of illnesses provoked, for example, by stress(20). Support relationships at work, from colleagues and management alike, favor the resolution of problems and consequently contribute to stress reduction, as well as providing wellbeing.

This study with agentes socioeducadores determined that interpersonal relationships were problematic among these workers. The agentes revealed difficulties in working as a team, as well as a shortage of human resources ${ }^{(21)}$. Confrontational interpersonal relationships hinder supportive relationships at work. The work of agentes socioeducadores has specific characteristics which deserve highlighting and which may explain the results found, such as: the unpredictability, the risk of aggression, the responsibilities of the role of educator, the state of constant alert, the accelerated rhythm of work, the need for physical preparation for situations involving restraint, and speed in taking decisions. These characteristics indicate the high psychological demands which are part of these workers' routine work; further, they are associated with greater strain and tension, which, in the worker, translate as tiredness, forgetfulness, insomnia, somatization and anxiety characteristics of MPDs.

Workers with signs of distress, sadness, tiredness and forgetfulness, (among others) need to be aware of how serious these are and avoid trivializing them, as they form evidence of strain and illness. In this sense, by indicating the presence of the latter, the abovementioned signs may be assisting in the construction of strategies which may avoid - at an early stage - the worsening of mental health. The ongoing process of improving quality of life and work for the agentes brings benefits for FASE as much as the workers themselves.

It is worth noting the importance of the nurse, as an active member of the services working for workers' Health and Safety, in being alert to occupational risks and hazards(22), thus assisting in the promotion of healthy working environments.

\section{Conclusions}

A high prevalence $(50.1 \%)$ of MPD was identified among the agentes socioeducadores of the CASE/ RS. The epidemiological survey undertaken, despite the limitations inherent to cross-sectional studies (not being possible to relate cause and effect) allowed the initial exploration of the factors associated with MPDs, and points to evidence of the relevancy of the problem among this class of workers. However, further research is necessary to confirm the consistency of the associations found.

A positive and significant association was determined between active work, high strain, and the occurrence of MPD. These results confirm the assumption of the Demand-Control Model, principally on the subject of psychological demands having negative influences on workers' health: in this study, the high psychological demands seem to have a negative influence on the agentes socioeducadores' work, whether or not the workers have high control over the work. These results contribute to public health, most specifically to the field of workers' health, bearing in mind that MPDs constitute an important health problem which often leads to absenteeism, and which has economic consequences and effects for the health system, the institutions or companies, and the workers themselves. 
The present study presents a panorama of the agentes socioeducadores' work and its repercussions on their psychiatric health, and provides support for the planning and implementation of health promotion actions.

It is concluded that the prevention of MPDs involves an understanding of the psychosocial factors and stress present in the workplace environment. Such an understanding can help in developing strategies for health promotion and for the prevention of MPDs in this class of worker - such as: promoting activities involving consciousness-raising, education and guidance, carrying out actions which promote workers' health (leisure and physical activities, and activities of integration and participation), and developing participative management activities aimed at integrating the agentes socioeducadores into the institution's organizational process as actors in resolving problems; and carrying out periodical monitoring of the workers regarding health conditions.

\section{References}

1. I Programa de Execução de Medidas Socioeducativas de Internação e de Semiliberdade do Rio Grande do Sul (PEMSEIS) [Internet]. Porto Alegre; 2002. [acesso 12 out 2009]. Disponível em: http://www.fase.rs.gov.br/ arquivos/1189084873pemseis.pdf

2. Karasek RA, Theörell T. Healthy work-stress, productivity, and the reconstruction of working life. New York: Basic Books; 1990.

3. Alves MGM, Chor D, Faerstein E, Lopes CS, Werneck GL. Short version of the "job stress scale": a Portuguese-language adaptation. Rev Saúde Pública. 2004;38(2):164-71.

4. Araújo TM, Graça CC, Araújo E. Occupational stress and health: contributions of the Demand-Control Model. Ciênc Saúde Coletiva. 2003;8(4):991-1003.

5. Cerchiari EAN, Caetano D, Faccenda O. Prevalência de Transtornos Mentais Menores em Estudantes Universitários. Estud Psicol. 2005;10(3):413-20.

6. Maragno L, Goldbaum M, Gianini RJ, Novaes Hillegonda MD, César CLG. Prevalence of common mental disorders in a population covered by the Family Health Program (QUALIS) in São Paulo, Brazil. Cad Saúde Pública. 2006;22(8):1639-48.

7. Tavares JP, Beck CLC, Magnago TSBS, Zanini R, Lautert L. Minor psychiatric disorders among nurses university faculties. Rev. Latino-Am. Enfermagem. 2012;20(1):175-82.

8. Araújo TM, Aquino E, Menezes G, Santos CO, Aguiar L. Aspectos psicossociais do trabalho e distúrbios psíquicos entre trabalhadoras de enfermagem. Rev Saúde Pública. 2003;37(4):424-33.

9. Nascimento CL Sobrinho, Carvalho FM, Bonfim TAS, Cirino CAS, Ferreira IS. Work conditions and mental health among doctors from Salvador, Bahia, Brazil. Cad Saúde Pública. 2006 Jan;22(1):131-40.

10. Ulhôa MA, Marqueze EC, Lemos LC, Silva LG, Silva $A A$, Nehme $P$, et al. Minor psychiatric disorders and working conditions in truck drivers. Rev Saúde Pública. 2010;44(6):1130-6.

11. Nussbaumer L, Dapper V, Kalil F. Agravos relacionados ao trabalho notificados no Sistema de Informações em Saúde do Trabalhador no Rio Grande do Sul, 2009. Bol Epidemiol. 2010;12(1):5-8.

12. Mari JJ, Williams P. A validity study of a psychiatric screening questionnaire (SQR-20) in primary care in the city of São Paulo. Br J Psychol. 1986;148:23-6.

13. Castells MA, Furlanetto LM. Validity of the CAGE questionnaire for screening alcohol dependent inpatients on hospital wards. Rev Bras Psiquiatria. 2005;27(1):54-7.

14. Gonçalves DM, Stein AT, Kapczinski F. Avaliação de desempenho do Self-Reporting Questionnaire como instrumento de rastreamento psiquiátrico: um estudo comparativo com o Structured Clinical Interview dor DSM-IV-TR. Cad Saúde Pública. fev 2008;24(2):380-90. 15. Hosmer DW, Lemeshow S. Applied Logistic Regression. New York: Wiley; 2000.

16. Kirchhof ALC, Magnago TSBS, Camponogara S, Griep RH, Tavares JP, Prestes FC, et al. Condições de trabalho e características sócio-demográficas relacionadas à presença de distúrbios psíquicos menores em trabalhadores de enfermagem. Texto ContextoEnferm. jun

2009;18(2):215-23.

17. Braga LC, Carvalho LR, Binder MCP. Working conditions and common mental disorder among primary health care workers from Botucatu, São Paulo State. Ciênc Saúde Coletiva. 2010;15(1):1585-96.

18. Porto LA, Carvalho FM, Oliveira NF, Silvany Neto AM, Araújo TM, Reis JFB, et al. Association between mental disorders and work-related psychosocial factors in teachers. Rev Saúde Pública. 2006;40(5):818-26.

19. Sanne B, Mykletun A, Dahl AA, Moen BE, Tell GS. Testing the Job demand-control-support model with anxiety and depression as outcomes: the Hordaland Health Study. Occup Med. (Lond). 2005;55(6):463-73. 20. Fonseca ISS, Moura SB. Apoio social, saúde e trabalho: uma breve revisão. Revista Eletrónica Internacional de La Unión Latinoamericana de Entidades 
de Psicológia. 2008 Dic;15. [acesso 15 nov 2011]. Disponível em: http://psicolatina.org/15/apoio.html 21. Grando MK, Kirchhof ALC, Beck CLC, Trindade LL. As cargas de trabalho em um Centro de Apoio SócioEducativo. Online Braz J Nurse. [periódico na Internet]; 2006;5(1). Disponível em: http://www.objnursing.uff. $\mathrm{br} /$ index.php/nursing/login?source $=\% 2 \mathrm{~F} \% 2$ Findex.php \%2Fnursing\%2Farticle\%2Fview\%2F198\%2F47

22. Magnago TSBS, Lisboa MTL, Griep RH, Kirchhof ALC, Guido LA. Psychosocial Aspects of Work and Musculoskeletal Disorders in Nursing Workers. Rev. Latino-Am. Enfermagem. 2010;18(3):429-35. 